\title{
ADHD Phenotype Related To Pediatric Obstructive Sleep Apnea (OSA) and ADHD as an Inflammation of the Prefrontal Cortex
}

\author{
Mohannad Mannaa* \\ Department of Pediatrics, University of Illinois College of Medicine, USA
}

Submission: December 07, 2017; Published: March 01, 2018

*Corresponding author: Mohannad Mannaa, Division Head, Pediatric Pulmonary and Sleep Medicine, Department of Pediatrics, UIC-Peoria, University of Illinois College of Medicine, USA, Email: mohannadmannaa@gmail.com

\section{Opinion}

Pediatric OSA can give symptoms that mimic attention deficit hyperactivity disorder (ADHD). Both have similar symptoms of focus problem, memory loss, mood swings, hyperactivity, restlessness, poor school performance and decreased cognitive function. Even snoring is associated with higher level of inattention and hyperactivity. Snoring children with ADHD could have their ADHD eliminated if their habitual snoring were effectively treated [1].

Researchers speculate that ADHD is associated with hypo arousal (a state of increased sleepiness) rather than hyper arousal. Hyperactivity could be a coping mechanism to counteract the daytime sleepiness experienced by these kids [2].

The deceiving response of stimulant medication like methylphenidate in the OSA-ADHD phenotype kids could be explained by the hypo arousal theory. The stimulant medicationreplaces their hyperactivity to keep them stimulated way from their hypo arousal state.
We could explain the pathogenesis of ADHD in obstructive sleep apnea (OSA) through an inflammatory mechanism caused by OSA which involves the prefrontal cortex. There is abundant evidence that inflammatory mechanisms within CNS contribute to cognitive impairment via cytokinemediated interactions between neurons and glial cells [3].

OSA is a proven systemic inflammatory status that can be measured by high sensitivity C- reactive protein (hs CRP), and the magnitude of the hs CRP could be a major determinant of the neurocognitive deterioration related to OSA [4]. It was also suggested that polymorphism of interleukin-1 (IL1) receptor antagonists' is present in families and subjects suffering from ADHD.

There are two types of inflammation. The first type is classical inflammation that produce pain. The second type is achronic slow cellular inflammation that is below the perception of pain. The cellular inflammation causes disruption in the cellular signaling networks in individual cells that are required for the body's organs to run at optimum efficiency.

OSA

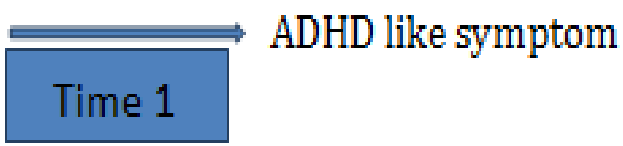

\section{ADHD like symptom}

\section{Time 2}

Figure 1: OSA-ADHD phenotype and treat it in a timely manner before it becomes irreversible.

Sometimes OSA-ADHD phenotype doesn't resolve or partially improves after treating OSA. I suggest as in Figure 1 that there is a time factor when these prefrontal cortex inflammatory changes are reversible but after undetermined time these changes become irreversible; prefrontal cortex remodeling.

We speculate that certain food may affect the level of ADHD if that food is pro- inflammatory and promote more 
inflammation of the prefrontal cortex. This is could explain how food might play a role in ADHD pathogenesis. Our recommendation for all pediatricians and physicians to look for the OSA-ADHD phenotype and treat it in a timely manner before it becomes irreversible.

\section{References}

1. Chervin RD, Dillon JE, Bassetti C, Ganoczy DA, Pituch KJ, et al. (1997) Symptoms of Sleep Disorders. Inattention and Hyperactivity in Children. Sleep 12(20): 1185-1192.
2. Bartholomew K, Owens J (2006) Sleep and ADHD: A review. Med Health R I 89(3): 91-93.

3. Wilson CJ, Finch CE, Cohen HJ (2002) Cytokines and cognition-the case for a head-to-toe inflammatory paradigm. J Am Geriatr Soc 50(12): 2041-2056

4. David Gozal, Crabtree VM, Capdevila OS, Witcher LA, Kheirandish-Gozal L, et al. (2007) C-reactive Protein, Obstructive Sleep Apnea, and Cognitive Dysfunction in School-aged Children. American Journal of Respiratory and Critical Care Medicine 176(2): 188-193.

\section{Your next submission with Juniper Publishers will reach you the below assets}

- Quality Editorial service

- Swift Peer Review

- Reprints availability

- E-prints Service

- Manuscript Podcast for convenient understanding

- Global attainment for your research

- Manuscript accessibility in different formats

( Pdf, E-pub, Full Text, Audio)

- Unceasing customer service

Track the below URL for one-step submission https://juniperpublishers.com/online-submission.php 